УДК $94(477.42)$ «192» : 613

DOI: https://doi.org/10.33782/eminak2020.3(31).442

\title{
СТАН І ПРОБЛЕМИ У СФЕРІ ОХОРОНИ ЗДОРОВ'Я НА ВОЛИНІ У РОКИ НЕПУ (1921-1928 РР.)
}

\author{
Ігор Власюк \\ Житомирський державний університет імені Івана Франка (Житомир, Україна) \\ e-mail: vlasyuk@zu.edu.ua \\ ORCID:https://orcid.org/0000-0003-4679-4101
}

У статті досліджено стан і проблеми у сфері охорони здоров'я на Волині в роки нової економічної політики (1921-1928 рр.). Проаналізовано заходи боротьби з епідеміями та найбільш поширеними хворобами того часу. Проведено порівняльний аналіз розвитку цієї галузі у названий період і дорадянський час.

Ключові слова: охорона здоров'я, епідемії, Волинь, радянська влада, нова економічна політика

Проблеми у сфері охорони здоров'я в Україні на сучасному етапі потребують прийняття правильних рішень відповідних органів влади, а також актуалізують дослідження з вивчення досвіду їхнього вирішення у попередні епохи, особливо у XX ст. Загалом, тема завжди була і залишається значущою для українського суспільства.

Дана проблема знайшла своє відображення як у наукових працях радянського періоду, так і в низці сучасних досліджень. Серед останніх можна виділити такі праці: І. Адамська (партійно-державна політика в галузі охорони здоров'я в Українській СРР (1919-1929 рр.))ํㅜㄹ і кадрового забезпечення в Україні, діяльність органів влади у боротьбі з епідеміями та соціальними захворюваннями у першій половині 1920-х рр.)2; М. Мельничук (правове регулювання охорони здоров'я населення в УСРР у 1921-1929 рр.)3; М. Мельничук і Т. Томляк (медико-санітарна діяльність і соціальна допомога населенню УСРР у 1921-1929 pр. Українського товариства Червоного Хреста) ${ }^{4}$; М. Олійник (стан охорони здоров'я на Поділлі у 1921-1925 рр.) ${ }^{5}$; С. Лупаренко (особливості розвитку системи охорони материнства й дитинства в Україні в 1920-

\footnotetext{
${ }^{1}$ Адамська І.Г. Партійно-державна політика в галузі охорони здоров'я в Українській СРР (19191929 рр.): автореф. дис... канд. іст. наук: 07.00.01. Київ: Київський національний університет імені Тараса Шевченка, 2011. 15 с.

${ }^{2}$ Кузьмінець Н.П. Охорона здоров'я в Україні в першій половині 1920-х років: історичний аспект. Наукові записки [Вінницького державного педагогічного університету імені Михайла Коцюбинського]. Серія: Історія. 2014. Вип. 22. С. 49-54.

3 Мельничук М. Правове регулювання охорони здоров'я населення УСРР (1921-1929 рр.): дис... канд. юрид. наук: 12.00.01. Київ: Нац. пед. ун-т ім. М.П. Драгоманова, 2016. 223 с.

4 Мельничук М., Томляк Т. Українське товариство Червоного Хреста: медико-санітарна діяльність і соціальна допомога населенню УСРР у 1921-1929 pp. // Наукові записки [Вінницького державного педагогічного університету імені Михайла Коцюбинського]. Серія: Історія. 2018. Вип. 26. C. 58-64.

5 Олійник М. Стан охорони здоров'я на Поділлі в 1921-1925 pp. // Наукові записки Тернопільського національного педагогічного університету імені Володимира Гнатюка. Серія: Історія. 2014. Вип. 1(1). С. 39-43.
} 
1940-х рр.)6 та ін.

Однак, незважаючи на те, що радянська Волинь згадується в окремих з названих праць, поки немає комплексного дослідження стану і проблем у сфері охорони здоров’я у цьому регіоні в роки нової економічної політики (1921-1928).

У сфері охорони здоров'я населення важливе значення мало утворення Народного комісаріату охорони здоров'я УСРР (21 січня 1919 р.). Йому підпорядковувалися відділи охорони здоров'я при місцевих виконкомах у губерніях. Загалом же, після виходу відповідного декрету Раднаркому УСРР від 17 травня 1919 р. відбулася націоналізація усіх лікувальних установ та аптечної справи в республіці7.

Одним з поширених явищ повоєнного часу на початку 1920-х рр. були епідемії на захворювання тифом, холерою й ін., що були викликані як природними причинами, так і соціальними негараздами. На липневих нарадах надзвичайного санітарного комітету Волинського губернського відділу охорони здоров'я (далі - губздраву) 1921 р. було визнано за необхідне терміново вжити таких заходів у боротьбі із холерою: негайно відкрити холерні бараки та лікарсько-спостережні пункти у Житомирі та по всіх повітах; посилити санітарний нагляд за всіма харчовими продуктами та водою; посилити лікарський нагляд на залізницях і за біженцями, у всіх їдальнях, на фабриках, заводах та установах; негайно влаштувати санітарну карету для перевезення осіб, які захворіли на холеру й ін. ${ }^{8}$ Санітарно-просвітницькими відділами було віддруковано велику кількість протихолерної літератури, яку було розіслано по всіх повітах; організовувалися лекції на відповідну тему тощо9.

Лише з 1 липня до 1 серпня 1921 р. у містах і повітах Волинської губернії було зафіксовано 268 випадків захворювань на тиф, 99 - на дизентерію, 98 - на туберкульоз ${ }^{10}$. Однак, у 1921 р. фінансовий стан губздраву був критичним: замість необхідних для потреб населення 250-300 млн. крб. на місяць він отримував лише 8090 млн. крб. 11

У Житомирі в 1922 р. було відкрито новий шпиталь на 300 місць для тифозних хворих ${ }^{12}$. Також на рівні УСРР було прийнято постанову «Про протихолерну кампанію у 1923 р.», в якій пропонувалося встановити трикратні щеплення проти холери та тифу для таких груп населення: червоноармійці; медперсонал і службовці лікарняних закладів; робітники та службовці усіх державних, кооперативних та приватних закладів і підприємств; переселенці; особи, які перебувають у місцях позбавлення волі; учні та педагогічний персонал в усіх навчальних закладах; діти у дитячих будинках. Також важливе значення надавалося таким заходам як обов'язкове перебування хворих на холеру у лікарнях, підозрілих на цю хворобу та ізоляцію осіб, які були заражені вірусом; обладнання холерних лікарень та ізоляційних приміщень; обов'язкова дезінфекція приміщень у випадку виявлення в них холери; забезпечення робітників і службовців усіх видів підприємств та організацій кип'яченою водою, дотримуватись вимог санітарного нагляду; судові органи

\footnotetext{
6 Лупаренко С.Є. Розвиток системи охорони материнства й дитинства в Україні в 1920-40-х рр. // Педагогіка вищої та середньої школи. 2013. Вип. 37. С. 452-457.

7 Кузьмінець Н.П. Охорона здоров'я в Україні в першій половині 1920-х років... С. 50.

8 Волынский пролетарий. 1921. 9 июля (№ 5). С. 4.

9 Волынский пролетарий. 1921. 14 июля (№ 9). С. 3.

10 Державний архів Житомирської області (далі - ДАЖО). Ф. Р-1657. Оп. 4. Спр. 42. Арк. 7.

11 Волынский пролетарий. 1921. 27 сентября (№ 70). С. 4.

12 Волынский пролетарий. 1922. 1 января (№ 151). С. 2.
} 
мали поза чергою розглядати справи, пов'язані з правопорушеннями у цій сфері13.

Станом на лютий 1921 р. серйозними проблемами для діяльності Волинського губернського відділу охорони здоров'я були: нестача досвідчених і відповідальних працівників (через недостатні кошти на їх утримання); відсутність необхідних приміщень і предметів обладнання для відкриття лікарських закладів; недостатнє постачання продуктів харчування для потреб лікарень; складнощі з ремонтом приміщень і нестача засобів перевезення. Також заважала роботі неузгодженість вимог місцевих установ і центру у цій сфері14.

У звіті про діяльність губздраву за квітень 1923 р. повідомлялося про 2 наради санітарних лікарів Житомира, на яких було розглянуто питання профілактичного характеру (план протихолерних щеплень; обстеження джерел водопостачання та харчових продуктів; обстеження хворих, яких кладуть до лікарень, на холерний вібріон і тиф). Також відбулося засідання комісії щодо укладання програми санітарної грамоти у дитячих будинках; проведено лікарсько-педагогічну конференцію разом із секцією охорони здоров'я, на якій було розглянуто питання про проведення протитуберкульозного тижня серед дітей, норми харчування дітей у дитячих будинках.

Робота відділу відбувалася в особливо важких умовах через фінансові складнощі; ще більш погіршилося матеріальне становище лікарських закладів у продуктовому та господарському відношеннях, були заборгованості по зарплатах. Наприклад, зазначалося, що низькою була якість м'яса. Цукор, сіль, мило постачалися лише на 33\%. Заборгованість губздраву складала на квітень 1923 р. 21517 крб., оскільки кошти, які надходили з центру, були недостатніми та задовольняли ці потреби лише на 50\%; у забезпеченні медикаментами - на 60\%; не вистачало білизни 15 .

В усіх школах, дитячих будинках, на підприємствах та в організаціях проводились противіспяні заходи: було щеплено 4048 чол. У місцях позбавлення волі відбувалася кампанія протихолерних щеплень. Проводилася боротьба з тифом і його наслідками, у результаті якої вдалося припинити поширення цієї хвороби. За поширення недоброякісних медикаментів було складено 9 протоколів притягнення таких осіб до судової відповідальності. В особливо важкому становищі перебувала сільська мережа системи охорони здоров'я в губернії, оскільки її було переведено 3 бюджету на самообкладання селян. Незважаючи на укладення відповідних договорів, надходження складали усього $30 \%$ від суми, закладеної в них ${ }^{16}$.

У 1923 р. лікарські заклади в губернії були у задовільному стані. У кожному повіті існувало до 15 лікарень, амбулаторій і фельдшерських пунктів. Усю цю мережу, за винятком міст, було передано на утримання селянам за договорами. Однак, вони неохоче виконували покладені на них обов'язки, перебуваючи часто у скрутному становищі. Договори виконувалися лише на 30\%. Відвідуваність цих закладів значно збільшилася, хоча й поширеним тоді залишалося знахарство.

У містах санітарний стан був незадовільним у зв'язку з відсутністю водогонів. За лютий 1923 р. було виявлено 74 захворювання на висипний тиф, 142 - на поворотний, 13 - черевний. Найбільше випадків (135) було у Житомирі. Роботу губздраву було спрямовано на створення венеричної поліклініки у Житомирі, боротьбу із за-

13 ДАЖО. Ф. Р-154. Оп. 2. Спр. 1. Арк. 564.

14 ДАЖО. Ф. Р-2686. Оп. 1. Спр. 54. Арк. 37.

15 ДАЖО. Ф. Р-28. Оп. 1. Спр. 1097. Арк. 107-108.

16 ДАЖО. Ф. Р-28. Оп. 1. Спр. 1097. Арк. 108зв.-109.

Eminak, 2020, 3 (31) 
хворюваністю на туберкульоз і тиф, особливо у місцях позбавлення волі. Там проводилася дезінфекція камер, одягу та білизни, а також противіспяні щеплення. Розроблялися плани розвитку сільської мережі лікарських закладів; проводилися обстеження лікарських закладів у повітах губернії тощо. Загалом, установа зазнала того року скорочення штатів 341 до 27 чол., що певним чином гальмувало її діяльність 17.

Стан охорони здоров'я на Волині та в УСРР у період НЕПу залежав від багатьох чинників, пов'язаних з наслідками громадянської війни, відсутністю належного фінансування галузі та її минулого, дорадянського розвитку. Так, у 1923-1925 рр. мережу лікарських закладів було пристосовано до нового адміністративнотериторіального поділу губернії. У кожному районі мали бути від 1 до 3 лікарських амбулаторій та 1 районна лікарня, в окружних центрах - окружна лікарня з підвищеною кваліфікацією медичної допомоги, наявністю певної кількості лікарівспеціалістів.

Аналіз розвитку системи охорони здоров'я на Волині показує, що порівняно 3 1913 р. кількість лікарень у 1925 р. мала тенденцію до збільшення (в Житомирі - 3 5 до 7, у селах - 29 до 37). Значно збільшилася у селах кількість амбулаторій (відповідно - з 22 до 79) і лікарняних ліжок (з 378 до 610). Також суттєво збільшилася кількість відвідувань амбулаторій (у Житомирі - з 44526 до 73 514; у районах - 3 85647 до 421 451). У той же час зменшилася кількість стаціонарних хворих у лікарнях і збільшилося відвідування їх лікарями на дому. Станом на 1925 р. також відбулися певні якісні зміни щодо самої мережі лікарських закладів, порівняно із попередніми роками НЕПу: їх було відремонтовано, забезпечено мінімумом інвентарю та медикаментів 18.

Загалом у 1924-1926 рр. у Волинській окрузі, порівняно з показниками 1913 р., відбулися певні позитивні зміни: наприклад, кількість лікарських дільниць збільшилася з 15 у 1913 р. до 33 у першій половині 1925/26 р.; лікарень - відповідно з 9 до 12; лікарів - з 15 до 43; кількість населення на 1 лікарську дільницю зменшилася з 42367 до 19094 осіб (при нормі Народного комісаріату з охорони здоров'я $15000)^{19}$.

У своїх звітах за 1924-1926 рр. представники Волинської окружної інспекції з охорони здоров'я виділяли такі проблеми: недостатня кількість лікарняних ліжок; відсутність транспорту для належної діяльності медичних ділянок; недостатня робота та нестача лікарів у профілактичному напрямі, що укорінилося ще з часів дорадянської земської медицини, а також пояснювалося інертністю їх; задовільний стан по районах округи лише 3 будівель (Кодня, Новоград-Волинський, Миропіль); низькі оклади лікарів, недостатні кошти для підвищення їх кваліфікації; відсутність квартир для лікарів; надто недостатня кількість зубних лікарів на селі; повна відсутність лікарсько-профілактичних установ для боротьби з венеричними захворюваннями тощо 20.

У серпні 1925 р. місцева влада Житомирської округи на Волині ставила такі завдання у сфері охорони здоров'я: збільшення медичної мережі на периферії згідно 3 бюджетними умовами; закінчити ремонт лікарських установ на селі та розпочати будівництво 2 нових лікарень; розподілити фонд білизни між лікарськими устано- 
вами сіл; поширити на селі санітарну працю, діяльність відділів охорони материнства та дитинства, мережу установ боротьби з венеричними захворюваннями; розробити план медичного постачання лікарень і забезпечення ліками населення; збільшити норми харчування для хворих до норм, визначених Народним комісаріатом фінансів на поточний рік; вжити заходів до ліквідації скарлатини у Житомирі21.

Важливе місце у галузі охорони здоров'я на Волині відводилося також установам з охорони материнства та дитинства (Охматдит). Їхня кількість поступово збільшувалася, переважно за рахунок організації консультацій і відкриття дитячих ясел. Установи Охматдиту проводили систематичну роботу з охорони дітей у навчальних закладах і дитячих будинках. Наприклад, вдалі щеплення проти дифтериту було зроблено у 1924 р. 22352 дітям; рентген було зроблено 582 дітям у Житомирі та 176 у Шепетівці. У дитячих сезонних яслах перебувало 386 дітей, дитячих таборах - $270^{22}$.

Як зазначав завідувач Житомирським окружним відділом охорони здоров’я Гехтман, Будинок матері та дитини у Житомирі був у першій половині 1920-х рр. завжди перевантажений (наприклад, у травні 1925 р. - на 152\%); одиноким матерям і дітям не вистачало місць у ньому, оскільки перебування їх у будинку було тривалим (7-8 місяців). Відмічалося поступове зниження дитячої смертності у будинку з 48\% у 1922 р. до 29\% у 1924 р. Важливе значення надавалося консультаціям по навчанню матерів щодо правильного годування та догляду за немовлятами, і це давало свої позитивні результати. Існувала нагальна потреба поширити такі консультації на селі задля збереження життя тисяч немовлят ${ }^{23}$.

С. Лупаренко звертає увагу на значні проблеми, що існували тоді у сфері материнства та дитинства в Україні (гінекологічні захворювання жінок, високий відсоток смертності дітей і матерів, низький санітарно-культурний рівень населення й ін.). Для вирішення їх передбачалося розширити мережу дитячих закладів, організувати стаціонарну пологову допомогу у сільській місцевості, заклади для обслуговування вагітних жінок тощо 24.

Мережа постійних установ з охорони материнства та дитинства збільшилася у сільській місцевості у 1925-1927 рр. на 33\% в частині організації дитячих консультацій, але ще недостатньо була поставлено роботу з консультування вагітних жінок. На утриманні молочної кухні (штучне вигодовування) знаходилося щорічно 200 дітей.

Робота у житомирському міському будинку матері та дитини округи проводилася у складних, часто незадовільних умовах: перевантаженість у 1925/26 р. складала 23,6\%; було велике підкидування дітей (46\%); наявність пошестей; тіснота приміщення; відсутність ізолятора; недостатність годувальниць для дітей і персоналу. На відміну від міста на селі мережа лікарів з охорони материнства та дитинства була достатньою, хоча там теж були свої проблеми. Дитячі будинки обстежувались на туберкульоз. Важливим моментом було залучення жінок до участі у роботі установ Охматдиту через ради соціальної допомоги, колективи батьків при яслах, суспільні організації. Оздоровчі кампанії у місті щодо організації дитячих таборів юних піоне-

\footnotetext{
21 ДАЖО. Ф. Р-308. Оп. 1. Спр. 6. Арк. 98-99.

22 ДАЖО. Ф. Р-28. Оп. 1. Спр. 1103. Арк. 87.

23 ДАЖО. Ф. Р-308. Оп. 1. Спр. 88. Арк. 9.

24 Лупаренко С.Є. Розвиток системи охорони материнства й дитинства... С. 454.
} 
рів проводилися за допомогою партійних і комсомольських осередків 25 .

Оздоровлення населення вважалося можливим тільки шляхом обізнаності його з проявами різних хвороб та іншими заходами у сфері охорони здоров'я (особливо сільського, де був високим відсоток неписьменних). Для цього у 1924 р. розпочалося створення Окружного будинку санітарної освіти, закупівля для нього відповідної літератури, муляжів, плакатів, проекційних засобів і діапозитивів, на що витрачено протягом року 8994 крб.

Окружна інспекція народної освіти вважала за необхідне перевести дитячі будинки, вяких утримувалися діти з різними захворюваннями (30\% від усіх губернських дитячих установ), на державний бюджет, оскільки місцевий не мав можливостей для їхнього повноцінного фінансування. 3 іншого боку, інспекція виступила рішуче проти скорочення коштів на утримання дітей з дитячих будинків до 15 крб. на рік, тому що це ставило їх у дуже скрутне становище. Зазначалося, що взимку 1925 р. ці діти хворіли на коросту через недостатнє забезпечення їх білизною; перебували у напівхолодних спальнях, багато не могли вийти на двір через відсутність пальто та взуття; школи припиняли свою роботу у холодний час, тому що діти навіть годину не могли сидіти у класі 26.

Проблеми фінансування сфери охорони здоров'я давали про себе знати і, наприклад, на 1925/26 бюджетний рік. Волинський окружний відділ охорони здоров'я на цей період потребував асигнувань на суму 800000 крб., а окружний фінансовий плановий відділ називав для нього контрольну цифру 530000 крб.; пропонувалося скорочення витрат на багато пунктів по усіх лікарсько-медичних та дитячих установах 27.

Однак, так звані соціальні хвороби продовжували у цей період вражати частину тогочасного суспільства. Порівняно з 1913 р. кількість хворих на туберкульоз на Волині у 1924 р. збільшилася з 8317 до 25 655, на сифіліс - з 4601 до 6033 . Хворобам цим не приділялось достатньо уваги ще до 1917 р., але точне обстеження їх у першій половині 1920-х рр. було неможливим через слабкість апарату, який мав їх реєструвати. Заходами боротьби з названими хворобами у 1922-1924 рр. було відкриття 3 туберкульозних і 3 венеричних диспансери, організація венеричних пунктів у кожній окрузі. У боротьбі із пошесними захворюваннями (малярія, тиф, кір, скарлатина й ін.), що активно проявилися у 1923-1924 рр., санітарні організації в губернії провели 57097 оглядів, 4118 дезінфекцій, провели 2786 лекцій (167 342 слухачі)28.

Особливої гостроти у роки НЕПу на Волині набуло питання надання допомоги психіатричним лікарням. 3 матеріалів губернської інспекції дізнаємось, що за наявності 50 ліжок для психічно хворих у психіатричному відділенні І-ої лікарні Житомира необхідно було відкрити психіатричну лікарню на 200 ліжок. За відсутності достатньої кількості місць частина хворих відправлялася на лікування до Вінниці 29.

Уся сільська лікарська мережа перебувала у колишніх приватних будинках, потребувала значного ремонту (нові помешкання на 50\%, щоб їх пристосовувати або будувати нові). Для цього необхідно було виділити мінімально на ці потреби з боку Народного комісаріату охорони здоров’я 115000 крб., однак Волинь отримала у

\footnotetext{
25 ДАЖО. Ф. Р-326. Оп. 1. Спр. 66. Арк. 193-194.

26 ДАЖО. Ф. Р-308. Оп. 1. Спр. 88. Арк. 11-13.

27 ДАЖО. Ф. Р-308. Оп. 1. Спр. 88. Арк. 175-179.

28 ДАЖО. Ф. Р-28. Оп. 1. Спр. 1103. Арк. 86-88.

29 ДАЖО. Ф. Р-28. Оп. 1. Спр. 148. Арк. 87.
} 
1925 р. лише 47500 крб., що не дозволяло провести необхідний ремонт ${ }^{30}$.

Стан роботи у сфері охорони здоров'я на Волині поступово поліпшувався. Про це, зокрема, свідчать тези доповідей з даного питання по Волинській окрузі станом на серпень-листопад 1927 р. Загалом, окружний виконком у цій сфері працював у напрямку організації профілактичних ділянок для попередження хвороб серед населення. Поширилася мережа лікувальних закладів у сільських районах, однак вона надалі потребувала децентралізації для наближення медичної допомоги до потреб населення. Кількість амбулаторних відвідувань була задовільною. Недостатньою була кількість відвідувань хворих на дому (24 на 1000 осіб), що було пов'язано із відсутністю транспорту в лікарняних установах.

Значно збільшилася праця лікарів по санітарному огляду на епідемічні захворювання. Смертність у лікарнях Волинської округи на 1927 р. була невеликою і складала 3,3\%. Завершувався капітальний ремонт більшості лікарень округи. Президія окружного виконавчого комітету пропонувала інспекції з охорони здоров'я продовжувати профілактичну роботу у містах і селах; збільшувати шпиталізацію пошесних хворих; ширше розгорнути роботу акушерок на селі тощо ${ }^{31}$.

Бюджет на діяльність Волинської окружної інспекції з охорони здоров'я поступово збільшувався: наприклад, у 1925/26 р. він складав 712664 крб., а у 1926/27 р. - 811363 крб. Було проведено повну перереєстрацію усього лікарського персоналу округи, а також статистичну роботу з обліку хворих у містах і селах.

Статистичні дані по Волинській окрузі у 1925-1927 рр. фіксують збільшення пологової допомоги (з 61\% до 70\%). Важливе значення, як і раніше, приділялося лікуванню «соціальних» хвороб, відмічалося зменшення кількості хворих на різні венеричні захворювання та туберкульоз 32 .

Окремо необхідно сказати про стан міста Житомира у сфері охорони здоров'я. Приріст населення у 1924-1926 рр. коливався у межах 16-17 на 1000 мешканців; смертність була нижчою за загальноукраїнські показники. Харчування населення можна було вважати задовільним. Епідемічний стан міста у 1926/27 р. характеризувався зниженням кількості захворювань на тиф, малярію, кір, скарлатину; шпиталізація хворих на черевний тиф складала 76,6\%, на скарлатину - 100\%33.

Допомогу у сфері охорони здоров'я надавали також медично-санітарні установи Червоного Хреста, яких у Волинській губернії станом на 1923/24 р. було усього 5, але поступово їхня кількість збільшувалася ${ }^{34}$.

Можна погодитись з висновками дослідження I. Адамської про загальнодоступність у цій сфері, а з іншого боку - класовий підхід і контроль партійно-державних органів, централізацію управління нею 35 .

Отже, стан у сфері охорони здоров'я на Волині у добу НЕПУ (1921-1928 рр.) був спочатку досить складним через наслідки громадянської війни. Відповідним органам влади довелося зіткнутися не лише з фінансовими та матеріальними проблемами для розвитку лікарняних закладів, а й низкою захворювань, епідемій, що по-

\footnotetext{
30 ДАЖО. Ф. Р-28. Оп. 1. Спр. 148. Арк. 117.

31 ДАЖО. Ф. Р-326. Оп. 1. Спр. 112. Арк. 187-187зв.

32 ДАЖО. Ф. Р-326. Оп. 1. Спр. 112. Арк. 188-190.

33 ДАЖО. Ф. Р-326. Оп. 1. Спр. 66. Арк. 191.

34 Мельничук М. Правове регулювання охорони здоров'я населення УСРР (1921-1929 рр.)... С. 82.

35 Адамська І.Г. Партійно-державна політика в галузі охорони здоров'я в Українській СРР (19191929 pp.)... C. $11-12$.
} 
требували негайних заходів для їхнього подолання. Загалом, у низці показників ситуація з охорони здоров'я у регіоні суттєво поліпшилася порівняно з показниками 1913 р. 3 іншого боку, мало місце збільшення захворювань населення на так звані соціальні хвороби (туберкульоз, венеричні й ін.). У розвитку цієї сфери, як показує досвід названих років, головні функції на себе взяла держава. Однак державним органам не завжди вдавалося ефективно вирішувати усі нагальні проблеми з охорони здоров'я, особливо у сільській місцевості. Потребують подальшого дослідження стан здоров'я дітей, у т. ч. в дитячих будинках, робота лікарняних закладів Житомира у період НЕПу.

\section{REFERENCES}

Adamska, I.H. (2011). Partiino-derzhavna polityka v haluzi okhorony zdorovia v Ukrainskii SRR (19191929 rr.) [The health care party and state policy in Ukrainian SSR (1919 - 1929)] (Extended abstract of Candidate's thesis). Kyiv [in Ukrainian].

Kuzminets, N.P. (2014). Okhorona zdorov'ia v Ukraini v pershii polovyni 1920-kh rokiv: istorychnyi aspekt [Health in Ukraine in the first half of 1920: historical aspects]. Naukovi zapysky Vinnytskoho derzhavnoho pedahohichnoho universytetu imeni Mykhaila Kotsiubynskoho. Seriia: Istoriia, (22), 49-54 [in Ukranian].

Luparenko, S.Ye. (2013). Rozvytok systemy okhorony materynstva y dytynstva v Ukraini v 1920-40kh rr. [The development of the system of maternal and child health in Ukraine in the 1920-40th]. Pedahohika vyshchoi ta serednoi shkoly, 37, 452-457 [in Ukrainian].

Melnychuk, M. (2016). Pravove rehuliuvannia okhorony zdorovia naselennia USRR (1921-1929 rr.) [Legal Regulation of Health Protection of the Ukrainian SSR's Population (1921-1929)] (Candidate's thesis). Kyiv [in Ukrainian].

Melnychuk, M. \& Tomliak, T. (2018). Ukrainske tovarystvo Chervonoho Khresta: medyko-sanitarna diialnist i sotsialna dopomoha naselenniu USRR u 1921-1929 rr. [Ukrainian Red Cross Society: health and social activities assistance to the population of the USSR in 1921-1929]. Naukovi zapysky Vinnytskoho derzhavnoho pedahohichnoho universytetu imeni Mykhaila Kotsiubynskoho. Seriia: Istoriia, (26), 58-64 [in Ukrainian].

Murashova, O.P. (2019). Sotsialna polityka radianskoi vlady v Ukraini u 20-kh rr. XX st. [Social policy of Soviet power in Ukraine in the 20's of the twentieth century] (Candidate's thesis). Vinnytsia [in Ukrainian].

Oliinyk, M. (2014). Stan okhorony zdorov'ia na Podilli v 1921-1925 rr. [Healthcare situation in Podillia region in 1921-1925]. Naukovi zapysky Ternopilskoho natsionalnoho pedahohichnoho universytetu imeni Volodymyra Hnatiuka. Seriia: Istoriia, 1 (1), 39-43 [in Ukrainian].

\section{Igor Vlasyuk}

(Zhytomyr Ivan Franko State University, Zhytomyr, Ukraine)

e-mail: vlasyuk@zu.edu.ua

ORCID: https://orcid.org/0000-0003-4679-4101

\section{State and Problems in the Field of Health Care in Volhynia during NEP Years} (1921-1928)

The state and problems in the field of health care in Volhynia during the years of the New Economic Policy (NEP) in 1921-1928 are examined in the paper. Measures to fight the epidemics and the most common diseases of that time are analyzed. A comparative analysis of the development of health care in the studied period and pre-Soviet times is made.

The state of health care in Volhynia at the time of the NEP (1921-1928) was initially difficult due to the consequences of the civil war. The province authorities had to face not only the financial and material problems of medical establishments development, staffing issues, but also the need to immediately overcome epidemics of various diseases (preventive and other measures). In general, in a number of rates, the health care situation in the region had signifi- 
cantly improved compared to the indices of 1913. On the other hand, there was an increase in the occurrence of so-called social diseases (tuberculosis, sexually transmitted diseases, etc.). In the development of this sphere, as the experience of the studied period shows, the main functions were taken over by the state. The state of work in the field of health care in Volhynia gradually improved, especially in 1925-1927 (repair of hospitals, reduction of epidemic diseases, work of maternity and childhood care institutions, etc.). However, state bodies were not always able to solve all pressing health issues effectively, especially in rural areas.

The state of children's health, including children in orphanages, and the activity of Zhytomyr medical establishments during the NEP need further research.

Keywords: health care, epidemics, Volhynia, Soviet power, New Economic Policy 